\title{
ARTISTIC FREEDOM AND ACADEMIC FREEDOM
}

\author{
Robert M. O’NeIL*
}

\section{INTRODUCTION}

The Cincinnati, Ohio, jury surely did the right thing by rejecting obscenity charges against Contemporary Arts Center Director Dennis Barrie following the exhibition of Robert Mapplethorpe's photographs.' Yet a different outcome at that trial might have forced higher courts to consider to what degree the fine arts enjoy protection under the first amendment, an issue that has been curiously neglected in the evolution of freedom of expression. First amendment protection of artistic expression and several related questions affecting both free expression generally and academic freedom in particular deserve more attention than they have received. These questions are the focus of this article.

The article addresses academic and artistic freedom from three perspectives. Part II discusses the constitutional status of an artist's freedom to create. Part III analyzes an artist's freedom to display or perform his or her works, particularly in college and university facilities. Part IV explores complex questions of freedom in funding for the arts-including, of course, the perplexing (and now partially resolved) debate over content restrictions on grants from the National Endowment for the Arts.

\section{II}

\section{Freedom to Create}

Surely the first amendment ought to protect the artist's creative process and product as fully as it protects the spoken and printed word. Legal scholars and practitioners of the arts have consistently assumed that art is

\footnotetext{
Copyright $\odot 1990$ by Law and Contemporary Problems

* Professor, University of Virginia; Director, Thomas Jefferson Center for the Protection of Free Expression.

1. See Kim Masters, Art Gallery Not Guilty of Obscenity: Cincinnati Jury Clears Mapplethorpe Exhibition of All Charges, Washington Post Al col 4-6 (October 6, 1990). The obscenity charges were not unexpected. Shortly before the opening of the Mapplethorpe exhibit in early April, 1990, the Contemporary Arts Center sought an injunction against threatened prosecution, but a federal judge declined to intervene. An arrest was made for violation of the Ohio obscenity laws soon after the show opened, although law enforcement officers were ordered by federal courts not to interfere with the continued display. The show went on as scheduled, with record crowds, while director Barrie awaited the criminal trial that occurred in late September and October. State v Mapplethorpe, 90-CRB11699A (Cincinnati Dist Ci October 5, 1990).
} 
"speech."2 But that assumption needs closer examination; the state of the law is less clear than these scholars assume. Artists familiar with the current state of the law are right to be uncomfortable. One scholar who recently reviewed the cases summarizes current doctrine with a realistic sense of resignation:

Artistic expression has been assigned derivative and second class status in the views of many first amendment thinkers, the Supreme Court, and other courts. [F]rom a first amendment perspective the ideal kind of expression is political discourse, and all other kinds of expression, including artistic expression, are accorded lower degrees of first amendment protection depending on their similarity to political expression. ${ }^{3}$

To test this conclusion, an independent review of the scope of first amendment protection for artistic expression is in order. In pursuing the constitutional question, "Is art protected?," it is necessary to bear in mind a logically antecedent question: "What is art?" Courts are not comfortable defining art. One recalls Justice Holmes' stern warning at the turn of the century: "It would be a dangerous undertaking for persons trained only to the law to constitute themselves final judges of the worth of pictorial illustrations." 4 Moreover, the very nature and concept of art is changing rapidly - with credit (or blame) to Andy Warhol and other pioneers of new forms of creative expression. ${ }^{5}$ In fact, much of what shocks many viewers about current art is more its novelty than its inherently abrasive content. Thus it becomes progressively more difficult even for art critics, let alone judges, to determine "what is art,"6 and this article will focus instead on the more familiar question of whether art is protected.

The search for sources of constitutional protection of artistic expression is not fruitful. Curiously, the Supreme Court has never defined precisely the scope of first amendment protection for the creative and performing arts. ${ }^{7}$ There are, however, several sources from which to glean useful hints. Nearly forty years ago, for example, in Burstyn $v$. Wilson,$^{8}$ the court considered the constitutionality of a New York statute permitting the banning of motion pictures on the ground they are "sacriligious." In striking down the statute, the Court held without dissent that "expression by means of motion pictures is included within the free speech and press guaranty of the First and Fourteenth Amendments."9 In so holding, the Court explained:

It cannot be doubted that motion pictures are a significant medium for the communication of ideas. They may affect public attitudes and behavior in a variety of ways, varying from direct espousal of a political or social doctrine to the subtle

2. See, for example, Zechariah Chafee, Free Speech in the United States 545-46 (Harvard Univ Press, 1941).

3. Sheldon H. Nahmod, Artistic Expression and Aesthetic Theory: The Beautiful, the Sublime and the First Amendment, 1987 Wis L Rev 221, 222.

4. Bleistein v Donaldson Lithographing Co., 188 US 239, 251 (1903).

5. See Note, Post-Modern Art and the Death of Obscenity Law, 99 Yale L J 1359 (1990) (authored by Amy M. Adler).

6. See Andrew Grundberg, Art Under Altack: Who Dares Say That It's No Good?, New York Times B1 col 3-4 (November 25, 1990); Leonard D. DuBoff, What is Art? Toward a Legal Definition, 12 Hastings Comm \& Ent L J 303 (1990).

7. See generally Nahmod, 1987 Wis L Rev 221 (cited in note 3).

8. Joseph Burstyn, Inc. v'Vilson, 343 US 495 (1952).

9. Id at 502 . 
shaping of thought which characterizes all artistic expression. The importance of motion pictures as an organ of public opinion is not lessened by the fact that they are designed to entertain as well as to inform. ${ }^{10}$

Arguably that judgment, or at least its logic, went beyond film, and carried full constitutional protection to all artistic media. ${ }^{11}$

Additional, if somewhat oblique, insight comes from cases inquiring into obscenity. During the three decades since the Court first sought to define obscenity and review procedures for its suppression, ${ }^{12}$ the Justices have stressed that judgments "in the area of freedom of speech and press ... must always remain sensitive to any infringement on genuinely serious literary, artistic, political or scientific expression."13 A particular work can be found obscene only if it lacks, inter alia, "serious . . . artistic . . . value." 14

These criteria compel consideration of the artistic qualities of works claimed to be obscene. As the outcome of the Mapplethorpe trial seems to suggest (since much sympathetic and apparently persuasive testimony related to the artistic qualities of Mapplethorpe's work), ${ }^{15}$ that mandate alone may have considerable value to the fine arts community. It may even be that when a given work is found to be "art," it cannot also be held obscene; the very notion of constitutionally unprotected art may be logically untenable-at least as far as obscenity is concerned. The same is not true under the newer child pornography laws recently sustained by the Supreme Court; ${ }^{16}$ much material that may violate these laws may also have considerable artistic merit, leaving unclear the relationship between the status of art and other exceptions to the first amendment. In any event, obscenity cases, because they do not address the issue, fail to provide any direct support for declaring that art is speech for constitutional purposes. Their language sharpens the inquiry for finding obscenity, but surely does not resolve the central issue.

Justice William O. Douglas, apparently alone on this as on many topics, once addressed constitutional protection of art directly. Dissenting in a 1960 case involving quite different matters, he argued that "the actor on stage or screen, the artist whose creation is in oil or clay or marble . . are beneficiaries of freedom of expression." 17 Yet even Justice Douglas never found the opportunity to apply these precepts to vindicate an artist's claim of free expression.

10. Id at 501 .

11. Later cases involving film review boards seemed to qualify that protection. See Times Film Corp. $v$ City of Chicago, 365 US 43 (1961).

12. See Roth $v$ United States, 334 US 476 (1957) (first attempt of Supreme Court to define obscenity).

13. Miller v Califormia, 413 US 15 (1973).

14. Id at 22-23.

15. Isabel Wilkerson, Obscenity Jurors Were Pulled Two Ways, New York Times A 12 col 4-6 (October 10,1990 ).

16. New York v Ferber, 458 US 747 (1982) (sustaining New York criminal statuce that prohibits persons from knowingly promoting sexual performances by children under the age of 16 by distributing material that depicts such performances).

17. Poe v Lillman, 367 US 497, 514 (1960) (Douglas dissenting). 
Artists can also turn for support to Southeastern Promotions, Ltd. v. Conrad, ${ }^{18}$ a first amendment case that comes close to addressing protection of artistic expression. In holding that a city could not exclude from a public auditorium performances of the rock musical "Hair," at least not without fairly elaborate procedural safeguards, the Court felt called upon to discuss briefly the nature of the activity the city authorities had summarily barred. ${ }^{19}$ The arbitrary and subjective basis the city gave for barring the musical would have sufficed, said the majority, "only if we were to conclude that live drama is unprotected by the first amendment-or subject to a totally different standard from that applied to other forms of expression." 20 No member of the Court argued that rock musicals should be so viewed. Yet this dictum suggesting that the first amendment protects artistic expression was not without an important limitation: "Each medium of expression, of course, must be assessed for first amendment purposes by standards suited to it, for each may present its own problems." 21 This addendum offers at least some basis for the artist's fear that creative and performing arts enjoy less than the full protection afforded the spoken and printed word.

Even in the lower courts, the case law is surprisingly meager, and the judicial views are in less than perfect accord. ${ }^{22}$ As recently as 1988, a federal appeals court sustained the removal of Richard Serra's "Tilted Arc" from Manhattan's Federal Plaza. ${ }^{23}$ In so doing, the court would do no more than concede that "artwork, like other non-verbal forms of expression, may under some circumstances constitute speech for first amendment purposes."24

So grudging a view of the creative arts is not unique. An earlier federal appeals court upheld the removal of controversial art from gallery space in a state university student center. ${ }^{25}$ The judgment reflected, in major part, the court's disparaging view of the paintings that provoked the dispute. Without deciding what degree of deference judges ought in principle to give to works of art, the court found the claim for protection weak in part because "there is

18. 420 US $546(1975)$.

19. Id at 569-72. A ruling in favor of the show's promoters would have required the Court to do no more than fault the city's shoddy procedures; glaring deficiencies in the way requests for auditorium space were handled made it unnecessary to decide whether or not the proposed use of the facility was clearly entitled to first amendment protection.

20. Id at 557 .

21. Id, citing Burstyn, 343 US at 503 .

22. See, for example, Ralph E. Lerner \& Judith Bresler, Art Law: The Guide for Collectors, Investors, Dealers and Artists 315-23 (Practicing Law Institute, 1989).

23. "Tilted Arc," commissioned and underwritten by the General Services Administration, was installed on the Federal Plaza in downtown Manhattan in 1981. It was an arc of steel 120 feet long, 12 feet tall, and several inches thick. It soon became an object of intense public debate and criticism because of its enormous size, and because it was designed to rust over time. After a public hearing in 1985, at which the sculptor was allowed to explain his views on the piece, the GSA decreed its removal, though insisting it "made no judgment whatsoever concerning the aesthetic value of the Tilted Arc." The removal order was ultimately sustained. See Serra v United States General Services Admin., 847 F2d 1045, 1048 (2d Cir 1988); Richard Serra, Art and Censorship, 14 Nova L Rev 323 (1990); Richard Serra, Tilted Art Destroyed, 14 Nova L Rev 385 (1990).

24. Serra, $847 \mathrm{~F} 2 \mathrm{~d}$ at 1048 .

25. Close v Lederle, 424 F2d 998 (1st Cir 1970), rev'g 303 F Supp 1109 (D Mass 1969). For the facts of the dispute and lower court decision, see text accompanying notes 48-49. 
no suggestion that, unless in its cheap titles, plaintiff's art was seeking to express political or social thought."'26 The court then compared the paintings before it to campus speaker bans, which in its view "involve a medium and subject matter entitled to greater protection than plaintiff's art."27 The implication seems clear and is consistent with the scholarly view cited earlier: ${ }^{28}$ art that conveys a political message or theme stands markedly higher in the constitutional order than art that is "merely art," however great its critical acclaim or its aesthetic appeal.

For example, a federal district court assessing a controversial sculpture stated that "the art form involved in this case constitutes speech within the meaning of the First Amendment and thus is entitled to constitutional protection"29_a statement that drew its principal support from the broad protection espoused in Southeastern Promotions. Moreover, the challenged sculpture embodied a primarily political message-in fact, political caricature of a kind that may be entitled to protection almost without regard to the medium of expression in which it appears. ${ }^{30}$

The Seventh Circuit, however, has been less willing to distinguish political and nonpolitical art. Several years ago, Judge Richard Posner observed that "freedom of speech and of the press protected by the first amendment has been interpreted to embrace purely artistic as well as political expression ... . unless the artistic expression is obscene in its legal sense"'31-although the court went on to hold that an artist could not resist a state college's relocation of his controversial art works from a highly visible campus gallery.

One can find a few other references to the constitutional status of artists and their works, but they are essentially cumulative. There seems to be a fairly firm consensus that art that conveys a political message is fully protected. Works whose merit is "exclusively artistic" sometimes fare less well. Such a dual standard may find little historic or philosophical support, ${ }^{32}$ but has proved remarkably durable and quite hard to dislodge.

Neither artists nor constitutional scholars concerned about the arts should take much comfort from the way this issue has been addressed. While no court has squarely rejected first amendment protection for the creative and performing arts, that fact offers small solace indeed-especially in view of the protection that seems to have been extended to such less ennobling media of communication as nude and topless dancing. ${ }^{33}$ The arts, and those who

26. Id at 990 .

27. Id.

28. See note 3 and accompanying text.

29. Sefick v City of Chicago, 485 F Supp 644, 648 (ND Ill 1979).

30. See, for example, Yorty v Chandler, 13 Cal App 3d 467, 91 Cal Rptr 709 (1971).

31. Piarowski v Chicago Community College, 759 F2d 625, 628 (7th Cir 1985).

32. Indeed, there is very early evidence of an assumption that artistic expression was of a rather high order and thus arguably entitled to protection. Zechariah Chafee cites a declaration of the Continental Congress in 1774 that basic freedom would include "the advancement of truth, science, morality and arts in general." Chafee, Free Speech in the United States at 545 (cited in note 2).

33. See, for example, Schad v Borough of Mt. Ephraim, 452 US 61 (1981). 
create and study them, deserve better in a society whose liberty is centrally tied to artistic as well as political expression.

One might simply continue to assume that, when and as necessary, the arts will get their due. Suggestions to the contrary are relatively few, and appear only in dicta ${ }^{34}$-though, for that matter, even the sympathetic statements seem to accompany judgments adverse to the artist and thus represent largely Pyrrhic victories. Alternatively, one could hope that litigation of these issues will eventually compel the courts to address an issue that has too long been left to implication. If, for example, the director of Cincinnati's Contemporary Arts Center had been convicted on obscenity charges for displaying the Mapplethorpe photographs, higher courts in Ohio would have been forced to appraise the medium of expression and to define much more clearly the extent of first amendment protection to which it is entitled.

Anything less than full first amendment protection for the arts seems anathema. To limit full protection to "political" speech would create an anomaly; a political cartoon with modest artistic value or a crude political sculpture would be fully protected, while an internationally recognized work of fine art would not be. Moreover, such a distinction would imply that even the finest and most widely acclaimed work of art makes little or no contribution to civic life or to the values served by democratic selfgovernment. To that suggestion, Alexander Meikeljohn has given the most persuasive answer:

[T] here are many forms of thought and expression within the range of human communication from which the voter derives the knowledge, intelligence, sensitivity to human values: the capacity for sane and objective judgment which, so far as possible, a ballot should express. [ ${ }^{35}$ ]

[The] people do need novels and dramas and paintings and poems, "because they will be called upon to vote." 36

\section{III}

\section{Freedom to Perform and Display Works of Art}

On the issue of the artist's right to display and perform controversial works, there is more direct law, and the results seem a bit more consistent. Yet here, too, the guidance provided by these results is less clear than the historic importance of the creative arts warrants.

\section{A. The "Performance" Cases}

Perhaps the easiest cases have been those arising on a college or university campus. Two recent cases involve a film ${ }^{37}$ and a play. ${ }^{38}$ In both cases, state college officials cancelled the performances on the basis of off-campus

34. For example, Close, 424 F2d at 990.

35. Alexander Meikeljohn, The First Amendment Is An Absolute, 1961 Sup Ct Rev 245, 256.

36. Id at 263 (quoting Professor Harry Kalven).

37. Brown "Bd. of Regents, 640 F Supp 674 (D Neb 1986).

38. DiBona v Matthews, 269 Cal Rptr 882 (Cal App 1990). 
criticism of their content. In each case, the courts held firmly in favor of the right to hold such performances, and thus added importantly to the stature of the performing arts. ${ }^{39}$

Brown $v$. Board of Regents involved a film scheduled to be shown at a theater in the art gallery of the University of Nebraska at Lincoln. The film in question was "Hail Mary," the most recent film directed by Jean-Luc Godard. Its most controversial feature-that which evoked the charge of blasphemywas a contemporary picturing of the birth of Christ. Protest against the film came from persons outside the campus, including a state senator who berated the theater director because some of her constituents thought the film sacrilegious or blasphemous. The director's superior bowed to this external pressure and cancelled the showing. A group of would-be viewers of the film promptly took the issue to federal court. ${ }^{40}$

The immediate result may well be less important than the reasoning and the broader implications for freedom of artistic display and performance within the academic community. In assessing the dispute, the court relied on a recent Supreme Court decision regarding the removal of books from school libraries, Board of Education, Island Trees Union Free School v. Pico. ${ }^{41}$ In Pico, the Supreme Court established firm and protective first amendment principles on that subject. ${ }^{42}$ The Court noted that the academic setting of Brown, in fact, made bowing to external political or religious pressure even less acceptable: "Even if the cause had been only the fact of controversy . . . cancellation would not have been justified, because action taken by an arm of the state merely to avoid controversy from the expression of ideas is an insufficient basis for interfering with the right to receive information." 43

Several factors may, however, modify the scope of this important decision. First, regardless of the content of the film, its artistic merit, or its message, the reason given for the cancellation was highly suspect. Thus the court might simply have concluded that a state university had no business banning any activity arguably protected by the first amendment in response to such pressures; such a holding would have avoided consideration of the degree of protection the film warranted. Second, film as a medium of expression had by this time received a substantial measure of first amendment protection. ${ }^{44}$ Thus, such a decision upholding the right to show a controversial film may not extend fully or easily to forms of expression litigated less frequently. Finally, the religious content or theme of the film may have afforded a measure of constitutional status that would not necessarily attach to art treating other themes, or to art lacking such a focus or message.

39. Brown, 640 F Supp at 681-82; DiBona, 269 Cal Rptr at 890-91.

40. Brown, 640 F Supp at 676-78.

41. 457 US 853 (1972).

42. Id at 871 .

43. Brown, $640 \mathrm{~F}$ Supp at 679.

44. Kingsley International Picture Corp. v Regents, 360 US 684 (1959). 
The other case 45 examining freedom of performance occurred later and potentially provides more protection to artists. A California junior college theater instructor chose for his class a play that treated race relations in a highly charged fashion. It included "a flurry of racial slurs and epithets" 46 just before a black police officer fatally shot a white suspect on stage. Community pressure, here too fueled partly by religious groups, caused the college administration to cancel performance of the play, even as a class exercise. A group of prospective playgoers sued to enjoin the ban.

In preventing the administrators from cancelling the performance, the court relied on the basic principles of Brown: strong community pressure would not justify banning from the campus controversial ideas, values, or views, even when embodied in an artistic medium rather than in lecture or newspaper form. The court also noted that the inappropriateness of the ban was even clearer here than in Brown, because cancellation of the play went to the heart of a college course, rather than simply limiting the extracurricular offerings of a campus theater. ${ }^{47}$

\section{B. The "Display" Cases}

Although these performance cases are consistent, and help to broaden protection of the arts, the same cannot so readily be said of cases involving exhibitions in university galleries. An early example, Close $v$. Lederle, ${ }^{48}$ involved removal by the University of Massachusetts at Amherst of an art exhibit from the student union. The exhibit, the work of a junior faculty member, was originally welcomed, but later was deemed by the university administration to be "inappropriate" after complaints about its presence in a heavily travelled corridor. The faculty member claimed the removal violated his first amendment rights. The district court was sympathetic, and ordered the administration to reinstate the exhibit. ${ }^{49}$ The court held the university art gallery to be a public forum. Since the artist had complied with the procedural rules for use of the forum, and since there was nothing "inappropriate" in the paintings, the judge found the removal of the paintings to be a violation of the artist's first amendment rights. Yet the court of appeals reversed, in part because of the view that wholly artistic expression deserves less protection than political expression. ${ }^{50}$ But the reviewing court also paid exceptional deference to the administration's judgment about what was "appropriate" or "inappropriate" for display in a well-travelled campus corridor. ${ }^{51}$

Close may have been biased by another factor: the paintings hung in a corridor through which many campus visitors could not help but pass-

45. DiBona, 269 Cal Rptr at 882 .

46. Id at 889 .

47. Id.

48. 303 F Supp 1109.

49. Id at 1120 .

50. Close, 424 F2d at 990.

51. Id. 
among them impressionable school children. To the court, that factor may have been the strongest basis for invoking a higher canon of taste: "Where there was, in effect, a captive audience, [the university administration] had a right to afford protection against 'assault upon individual privacy' . . . short of legal obscenity." 52

Thus, a public art display may set in motion a conflict between two sets of interests, demanding an accommodation not needed in the film and play cases. Art exhibits in highly visible spaces cannot so easily be avoided or bypassed by potentially surprised or offended viewers; that fact alone makes more complex the artist's claim to the right to display his work, whatever might be said of the antecedent interest in creating the work, or even (as in the case of the play) presenting the art to a class of his own for their comments or evaluation.

The other gallery case, Piarowski v. Chicago Community College, ${ }^{53}$ reaches, if with somewhat greater care, a consistent conclusion. An Illinois junior college art instructor was ordered by the administration to relocate three stained glass windows he had created for public display as part of an annual faculty exhibit. When the artist went to court, a decade and a half after Close, he found a more sensitive view of artistic expression, but fared no better in the end.

The court assumed, but saw no need to decide, that artistic expression enjoyed both first amendment protection and the full benefit of academic freedom. ${ }^{54}$ Two elements in the case, however, enabled the court to decide that no violation of the faculty member's first amendment rights had occurred when the adminstration ordered relocation of the windows. First, the college had properly cited a deep concern for the effects such an exhibit might have on its ability to recruit students. ${ }^{55}$ Second, the display was prominently visible: "the offending windows could be seen by people not actually in the gallery." 56 These factors helped to justify imposing canons of taste higher than the legal test of obscenity, thereby allowing the windows' relocation.

The critical question raised by the gallery cases is whether it is the medium or the setting that is constitutionally dispositive. Despite the uncertain status given the creative arts in both cases, the critical factor seems to be the location

52. Id. Compare Applegate v Dumke, 25 Cal App 3d 304, 101 Cal Rptr 645 (1972), a factually somewhat similar case that did not address the constitutional issue because of an apparent waiver of the artist's claims against a state university ban on the display of his works.

53. $759 \mathrm{~F} 2 \mathrm{~d}$ at 628 .

54. Id at 629 .

55. The court described the exhibit as follows:

One depicts the naked rump of a brown woman, and sticking out from (or into) it a white cylinder that resembles a finger but on careful inspection is seen to be a jet of gas. Another window shows a brown woman from the back, standing, naked except for stockings, and apparently masturbating. In the third window another brown woman, also naked except for stockings and also seen from the rear, is crouching in posture of veneration before a robed white male whose most prominent feature is a grotesquely outsized phallus (erect penis) that the woman is embracing

Id.

56. Id at 630 
of the exhibit-evoking the court's concern in one case for possible assault on a captive audience including school children, and in the other a concern that visible and offensive art works pre-empted prime campus gallery space for the display of material of less than universal appeal.

Such tensions are not confined to the courts or to constitutional judgments. They must also play a part in defining the extent and nature of academic freedom for the creative arts. The final report of last spring's Conference on Academic Freedom and Artistic Expression, after a resounding endorsement of maximum freedom for the creative process, addressed just the issue with which we have been dealing. ${ }^{57}$ The report closed by striking a somewhat different balance than the courts:

When academic institutions offer exhibitions or performances to the public, they should ensure that the rights of the presenters and the audience are not impaired by a "heckler's veto" from those who may be offended by the presentation. Academic institutions should ensure that those who choose to view or attend may do so without interference. Mere presentation in a public place does not create a "captive audience." Institutions may reasonably designate specific places as generally available or unavailable for exhibits or performances. ${ }^{58}$

How might such a view have altered the outcome of the Massachusetts and Illinois gallery cases? The report suggests, unlike the courts, that offense taken at a particular work, or fear that someone may take offense, would not justify removing the work once in place. But the report also recognizes that a generalized concern that student or faculty exhibits might contain controversial works would presumably justify a general policy that consigns them to a less prominent site. ${ }^{59}$

Finally, the conference report argues that presentation in a public place does not, by itself, create a captive audience. ${ }^{60}$ It seems, though, to leave open the possibility that such a condition might occur, and that, if it did, appropriate steps might be taken, consistent with the artist's freedom and the institution's own integrity. ${ }^{61}$

Thus, judgments of constitutional law and ideal precepts of academic freedom diverge on this issue-despite Judge Posner's effort at assimilating the two standards in the course of rejecting the Illinois college instructor's claim in Piarowski. ${ }^{62}$ The differences are, however, not so much on matters of principle-whether, for example, artistic expression is entitled to full protection-as on such issues as the degree of deference due a college's desire to shield visiting school children or to sustain its capacity to recruit future students.

The latter concerns may indeed generate institutional interests of a rather high order. The courts find them persuasive-superior not to the artist's interest in creating or exhibiting controversial works as such, but rather to the

57. The report is reprinted in 76 Academe 13 (July-August 1990).

58. Id.

59. Id.

60. Id.

61. Id.

62. 759 F2d 625. 
artist's wish not to have those works removed from the prominent location where the institution originally put them on display. A statement of principles of academic freedom would recognize the institution's dilemma but would insist that it be resolved in a different way-either by demanding that visitors be more tolerant, or by not committing such prominent space to potentially controversial work in the first place.

\section{IV \\ Freedom to ObTain Funding}

The third area of inquiry, constitutional limits on funding restrictions for the arts, may be the most difficult, and certainly is the most current. It has also elevated the arts to an unaccustomed level of political visibility and controversy. After a year and a half of sparring, the basic status of funding for the National Endowment for the Arts ("NEA")-and the inescapable corollary issue of content restrictions on NEA-funded art works-were resolved in late October in what appears to be a generally satisfactory compromise. ${ }^{63}$

In place of the Helms Amendment, ${ }^{64}$ a new grant-evaluation formula appears with two elements. The first is a simple (if ominous) declaration: in the broad provisions that cover grant-making, Congress has now directed the NEA to take into account "general standards of decency and respect for the diverse beliefs and values of the American public." 65 Such language seems to have no independent operative force, and would at most guide panels and agency officers among various desiderata to be applied in the review of proposals. Moreover, a spokesman for the endowment said soon after the congressional compromise that this language on "decency" was "nonbinding." 66

In its more detailed provisions, the new approach also represents a vast improvement over the Helms Amendment, which during its brief life both constrained and politicized the endowment. Gone from the new reauthorization is the Helms Amendment's restrictive language, which included terms that were imprecise and legally undefined and thus almost certainly unconstitutional. ${ }^{67}$ Artists seeking grants under the Helms Amendment were required to swear by oath that they would not transgress lines bounded by such terms as "sadomasochism" and "homoeroticism," and would not create or display works showing "individuals engaged in sex acts." 68 The oath took the form of a certification requirement to the "Request for Advance or Reimbursement." The new section of this form required

63. Pub L No 101-512, §103(b) (1990), amending 20 USC § 954(d).

64. Pub L No 101-121, § 304(a), 103 Stat 741 (1990), amending 20 USC $\S 954$. For a discussion of its provisions, see notes 67-69 and accompanying text.

65. Pub L No 101-512 §103(b).

66. Christopher Myers, Arts Backers are Pleased by Congress' 3 Year Reauthorization of NEA without Restrictions, Chron Higher Educ A 19 col 4 (November 7, 1990).

67. See Pub L No 101-121 § 304(a); see also note 71 .

68. Id. See HR Conf Rep No 101-264, 101 st Cong, Ist Sess 264 (1990). See also Stephen F. Rohde, Art of the State: Congressional Censorship of the National Endowment for the Arts, 12 Hastings Comm 
recipients to certify to compliance with certain "General Terms and Conditions for Organizations Grant Recipients." Paragraph Two of the Terms and Conditions contained language drawn directly from section 304(a). Therefore, in order for any grant funds to be released, the recipient had to certify in advance that none of the funds would be used "to promote, disseminate, or produce materials which in the judgment of the NEA . . may be considered obscene." 69

The change in the locus of decision seems at least as significant an improvement as the terminology. Under the Helms Amendment, the NEA was empowered to determine what was and was not obscene before making grants. ${ }^{70}$ In a field where scrupulous adherence to procedure has always been a quid pro quo for substantive restraint, the notion of inviting a grant-making agency to set its own standards on obscenity seemed especially abhorrent. Doubtless that informal process would have been enjoined by the courts had any of the several constitutional challenges to the Helms Amendment come to trial before the reauthorization. ${ }^{71}$

Under the congressional compromise, it is now clear that judgments about obscenity in the arts must be made by the courts. The standards to be applied are those that judges have fashioned over a period of more than three decades. ${ }^{72}$ The agency is empowered to seek recovery of a related grant only if a grant recipient is later convicted of an obscenity or child pornography charge. Grant recipients are no longer required to certify under oath that they will adhere to and enforce the statutory ban on any use of NEA funds for purposes the agency "may consider" obscene. ${ }^{73}$

The new 1990 reauthorization approach thus seems a major improvement in both substance and procedure. It removes the most intrusive and demeaning content restriction provisions of the Helms Amendment, and frees a benign agency from the role of policing grant recipients, which is especially important because the NEA must have the confidence of the arts community if it is to carry out the mission given it by Congress a quarter century ago.

The substitute approach is not, however, without potential problems. Reauthorization of the NEA with no content restrictions would have been preferable not only to artists and some members of Congress, but also to a most thoughtful bipartisan presidential commission that filed its report

\footnotetext{
\& Ent L J 353, 365 (1990); Note, Standards for Federal Funding of the Arts: Free Expression and Political Control, 103 Harv L Rev 1969 (1990).

69. Bella Lewitzky Dance Foundation v Frohnmayer, 59 USLW 2436 (CD Cal 1991).

70. Pub L No 101-121, §304(a).

71. While the Helms Amendment dealt in part with "obscene" material, and to that extent rested on firm and well-defined constitutional ground, the other key terms were not defined in the amendment or elsewhere, and thus would quite surely have been found vague or overbroad or both under well-settled first amendment principles. Thus, not surprisingly, the one case that has come to judgment reached just such a conclusion. See Bella Lewitzky Dance Foundation, 59 USLW 2436.

72. See Part II.

73. The NEA announced soon after passage of the reauthorization that it would no longer require grant recipients to sign a pledge of the kind that had been imposed during the previous year. Kim Masters, NEA Drops Obscenity Pledge; Arts Agency Decision Follows Hill Action, Washington Post C1 col 1 (October 30, 1990).
} 
shortly before Congress acted on the NEA's future. ${ }^{\mathbf{7 4}}$ In its key section, the commission recommended "against legislative changes to impose specific restrictions on the content of works of art supported by the Endowment."75 The report continued: "Content restrictions may raise serious constitutional issues, would be inherently ambiguous and would almost certainly involve the Endowment and the Department of Justice in costly and unproductive lawsuits."76

Some may argue that the new congressional approach does not even involve content restrictions, but simply the addition of a sanction for the violation of existing and constitutionally valid obscenity laws. Yet the effects of the new approach for the sensitive and conscientious artist may also be quite different from the effect that would have followed from reauthorization lacking such language and collateral sanctions.

In four specific ways, the reauthorization may still deter or make anxious the scrupulous creative person who seeks NEA support. The first and perhaps most obvious effect flows from the prominent reference to "decency."77 Despite the endowment's assurance that such language is nonbinding, and despite the absence of any enforcement provision or penalty, some members of the arts community find it not only offensive but ominous as well. The editor of the Kenyon Review, for example, calls the "decency" phrase "dangerously vague" and "incredibly ambiguous."78 She adds: "Although you don't have to sign anything, it once again leaves open a broad area that was never in question in the past." 79 Surely a conscientious artist might be uneasy both about the contours of "decency" and about their possible application to his or her creative works. Whether such anxiety attains constitutional stature remains, of course, a difficult question.

A second risk is the potential chilling effect created by the new approach to grant eligibility. While the judgment about what is obscene now rests with the courts, the sensitive and conscientious artist might well be fearful about the new collateral sanction the reauthorization creates. Such fears would be heightened by the state of the law reviewed earlier, and the uncertain basis of

74. Press release accompanying Independent Commission's Report to Congress on the National Endowment for the Arts (September 11, 1990) (on file with author); see also Kim Masters, Don't Restrict NEA, Panel Tells Congress; Report Urges Exclusion of Anti-Obscenity Language, Washington Post B 1 col 1 (September 12, 1990).

75. Independent Commission Report to Congress at 2 (cited in note 74).

76. Id at 89 .

77. Pub L No 101-512 § 103(b).

78. See Myers, Chron Higher Educ at A23 col 2 (cited in note 66). In March 1991, a group of performing artists and an artists' organization filed suit in federal court, with the support of the American Civil Liberties Union, alleging the unconstitutionality of the "general standards of decency" provision in the 1990 reauthorization. The suit argues that such a standard impermissibly restricts freedom of expression of grantees and applicants.

79. Id. The next week the NEA panel that reviews grants in the field of theater and drama asked for clarification of the term "decency" before its December meeting. Kim Masters, NEA Panel Seeks Decency Ruling, Washington Post C2 col 1-2 (November 15, 1990). Later, the panel that reviews proposals from artist-run organizations asked for assurance that "decency" will not be used as a criterion in judging grant applications despite the new language. Kim Masters, What Makes for Decency? Panel Seeks Clear Wording. Washington Post C4 col 1-3 (November 27, 1990). 
artists' expressive and creative freedoms. Until a few months ago, an established artist would probably have assumed that his or her works were immune from obscenity charges, and that, since no such charges had been brought in recent times, an NEA grant was quite secure.

The prosecution of Cincinnati's Contemporary Arts Center over the Mapplethorpe exhibit-despite the outcome-squarely challenges that assumption. However unusual the circumstances, artists can no longer dismiss the possibility of criminal jeopardy. Creative persons are bound to think twice before testing the limits of taste and decorum. The world of art will suffer from any such diminution of creative spirit.

A third danger is that museums and galleries may be less venturesome in seeking or displaying bold and controversial works. The events in Cincinnati again supply an illustration: the Mapplethorpe exhibit, as well as the artist, had received NEA support. ${ }^{80}$ Therefore, a gallery might be forced to forfeit an NEA grant if its director were convicted on charges like those filed against Barrie. Under those conditions, greater caution might be predicted on the part of those galleries that can least afford to forfeit government grants precisely because they tend to test the limits of taste by displaying the avant garde. Here too the world of creative art may stand to lose in the chillier climate that follows the compromise.

There is a fourth and final, if somewhat subtler, risk. Those who pressed so hard to make the NEA an administrative censor are not likely to retreat from the field because they lost this battle. In fact, it is quite possible to imagine all NEA grantees now becoming targets of self-appointed guardians of decency and propriety searching for evidence of obscenity in funded works. This is a frightening prospect indeed. It recalls vigilante movements of earlier and unhappy times in our national life, when the demon was sought in politics $^{81}$ rather than in art. But the parallel is uncomfortably close, and the potential chilling effect of private activity may be potentially greater even than that of government policy or prosecution.

Such risks and hazards do not, of course, make a constitutional case. They do, however, set the stage for possible challenges to the far less troubling language that replaced the Helms Amendment. ${ }^{82}$ Surely such a challenge would not be averted by Senator Helms' own claim that "refusing to subsidize something does not 'ban' it." 83 The body of law dealing with unconstitutional conditions is far too advanced to permit any branch of government to hide

80. See Rohde, 12 Hastings Comm \& Ent L J at 360 (cited in note 68).

81. John P. Roche, The Quest for the Dream 67-72 (Macmillan, 1963) (recounting the Palmer raids and the post-World War I anti-communist movements).

82. Compare favorably Advocates for Arts $v$ Thompson, 532 F2d 792, 797 (1st Cir 1976), a case that approaches this issue on its facts, in which the court expressed concern about New Hampshire's denial of a state grant to a literary magazine on the basis of one controversial poem, but declined to intervene on constitutional grounds in the magazine's favor

83. See Jesse Helms, Art, the First Amendment and the NEA Controversy: Tax-Paid Obscenity, 14 Nova L Rev 317, 320 (1990). 
behind distinctions between conditioned benefits and direct sanctions. ${ }^{84}$ More troublesome is the unavoidable truth that government cannot possibly fund every applicant or subsidize every work of art, and must therefore adopt and apply some neutral selective criteria.

Dean Geoffrey Stone poses the dilemma in this way:

\begin{abstract}
Although government may not ban offensive art, it does not necessarily follow that it must therefore subsidize such art. Surely, government is under no constitutional obligation to establish the NEA in the first place. Why, then, if it chooses to fund some art, should it be precluded from exercising reasonable judgment about the types of art it will support? For example, although government cannot ban "bad" art, it surely is under no constitutional obligation to fund "bad" art, even if it supports "good" art. Why, then, must government fund art that denigrates religion or promotes unlawful or undesirable conduct, or is inappropriate for children, or deeply offends others? There is a common sense difference between suppression and failing to subsidize, and government must have greater discretion in the latter situation than in the former. ${ }^{85}$
\end{abstract}

Dean Stone then offers his own compelling reply to a question he knows is not entirely rhetorical:

Reasonableness is not and cannot be, the constitutional standard for government efforts to restrict speech because the message is unwise, disagreeable, harmful or offensive. To the contrary, if there is a central principle in our first amendment jurisprudence, it is that government ordinarily may not restrict expression for such reasons, for such suppression distorts public debate, mutilates the thought process of the community, violates the equality of status in the field of ideas and elevates the government to the role of platonic censor. ${ }^{86}$

The crucial question remains: if government cannot fund all artists or all works, how must it choose? If it makes choices, it must adopt and apply standards. And if those standards are not simply broad and bland categories-for example, fund only oil paintings but not water colors, support metal sculpture but not plastic, favor portraits over landscapes-then there is inevitable potential for content differentiation. The difficulty is deciding when that differentiation abridges or inhibits freedom of expression in ways the first amendment will not allow.

Three further observations may help identify possible constitutional issues. It is only artists among all government grantees who forfeit benefits if they are convicted of violating obscenity laws; 87 a public employee, a scholarship holder, a public housing tenant-apparently anyone else who receives government support-would be immune. It is true that obscenity is more closely related to the nature of an NEA grantee's work and status than is the case for most other government beneficiaries. But consider then the other dimension of the grid: no other transgression by an NEA grantee would

84. See, for example, Lynn A. Baker, The Prices of Rights: Toward a Positive Theory of Unconstitutional Conditions, 75 Cornell L Rev 1185 (1990), and the many materials cited there.

85. Address by Geoffrey Stone at Loop Luncheon, 16-17 (October 18, 1990) (transcript on file with author).

86. Id at 19 .

87. But compare 18 USC $\$ 1464$ (1990), under which licensed broadcast stations may incur collateral sanctions for the broadcasting of obscene (as well as "indecent" or "profane") material on the air. See FCC v Pacifica Foundation, 438 US 726 (1978). 
cause the loss of the grant. If, for example, an artist is convicted of fraudulent art sales, or of selling drugs in the studio, or of disposing of toxic chemicals improperly, the NEA grant is unaffected. Ironically, it is the law violation most closely related to the artist's creative process-the most expressive of all the grantee's acts-that has been singled out as the basis of possible forfeiture. To focus in this way on artists among all government beneficiaries, and on their expression among all possible law violations, is at least deserving of further constitutional scrutiny.

A second possible concern relates to procedures. It is quite true that the new reauthorization ties the sanction-potential loss of a prior grant-to a court judgment of obscenity based on criteria that have received the Supreme Court's blessing. ${ }^{88}$ Yet those obscenity criteria, and the procedures by which they must be enforced to be constitutionally acceptable, are now to be used to impose not one but two quite unrelated penalties on the artist/grantee. The new approach is not unlike revoking a state university student's scholarship after a conviction for speaking on campus and creating a clear and present danger of lawless action, or barring from future government contracts any professional photographer convicted of child pornography. In each case, the primary sanction is imposed by procedures that are presumptively valid; courts upholding those procedures did not, however, realize they were also validating a secondary or collateral use of the primary sanction. Therein lies the problem.

The function here of the secondary sanction is not to allow government to avoid its obligations of due process, but rather to compound the consequences of a single speech-related offense on the basis of procedures designed only to support a single sanction. Courts have always been uneasy about allowing the outcome of one proceeding to trigger automatically a collateral consequence, even where due process was guaranteed in the primary proceeding. Moreover, the potential chilling effect of the secondary sanction may in this instance far exceed that of the primary sanction-if only because the value of a revoked NEA grant (like the student's scholarship or the photographer's access to government jobs) may be far greater than the fine one pays for a single brush with the criminal law. Thus it is fair to ask whether, especially in the area of expression, the procedures that have been validated for obscenity convictions were really intended also to support the punitive superstructure Congress has now imposed.

Finally, one must bear in mind that we are dealing with obscenity, in all its vagaries. When one considers the potential for regional variations in outcomes under the "community standards" formula, ${ }^{89}$ one might also ask whether the primary proceeding was intended to sustain such grave collateral consequences as the reauthorization contemplates. An artist creates a work in one city, but that work may eventually find its way before a jury in a much less enlightened community. That jury, applying its standards, may years later

88. Miller v Califormia, 413 US 15, 33 (1973).

89. Id. 
cause the forfeiture of an NEA grant made to the artist in a vastly different environment.

'It is far from clear whether any of these concerns alone, or all of them taken together, create doubts of constitutional magnitude. They are, however, worth exploring and bearing in mind as we watch the new NEA legislation take effect. The day may come when such arguments will need to be made. We cannot, after all, assume that every jury will be as reasonable as the one in Cincinnati.

\section{V}

\section{Conclusion}

Artistic freedom plays a potentially major role in shaping and safeguarding academic freedom. While the extent of constitutional protection for artistic expression remains surprisingly spare and imprecise, the case for such protection seems compelling. That protection should encompass the creative and performing arts in measure comparable to protection for the spoken and printed word, and for recognized media such as film. Protection for artistic expression must not be confined to the creation of works of art, but should extend also to the display, exhibition and performance of those works. To the same extent, government funding for the arts should not attempt to restrict an artist's freedom. Though government is under no duty to fund art at all, once it decides to do so, it may not use that funding to deprive the recipient of otherwise protected freedoms of expression. Artists, like speakers and writers, are engaged in an activity that properly claims, and deserves, the fullest measure of constitutional recognition. 
